5. Glasgow, A. M., and Chase, H. P.: Effect of pent-4-enoic, propionic and other short chain fatty acids on citrulline synthesis in rat liver mitochondria. Biochem. J. (in press.)

6. Holland, P. C., Senior, A. E., and Sherratt, H. S.A.: Biochemical effects of the hypoglycaemic compound pent-4-enoic acid and related nonhypoglycaemic fatty acids. Biochem. J., 136: 173 (1973).

7. Holland, P. C., and Sherratt, H. S. A.: Biochemical effects of the hypoglycaemic compound pent-4-enoic acid and related nonhypoglycaemic fatty acids. Biochem. J., 136: 157 (1973).

8. Hommes, F. A., Kuipers, J. R. G., Elema, J. D., Jansen, J. F., and Jonxis, J. H. P.: Propionic acidemia a new inborn error of metabolism. Pediat. Res., 2: $519(1968)$.

9. Lowry, O. H., Rosebrough, N. J., Farr, A. L., and Randall, R. J.: Protein measurements with the Folin phenol reagent. J. Biol. Chem., 193: 265 (1951).

10. Mamunes, P., Devries, G. H., Miller, C. D., and David, R. B.: Fatty acids in Reye's syndrome. Pediat. Res., 8: 436 (1974).

11. Morrow, G., Barness, L. A., Auerback, V. H., DiGeorge, A. M. Ando, T., and Nyhan, W. L.: Observations on the coexistence of methylmalonic acidemia and glycinemia. J. Pediat., 74: 680 (1969).

12. Oberholzer, V. G., Levin, B., Burgess, E. A., and Young, W. F.: Methylmalonic aciduria an inborn error of metabolism leading to chronic metabolic acidosis. Arch. Dis. Childhood, 42: 492 (1967).

13. Senior, A. E., and Sherratt, H. S. A.: Biochemical effects of the hypoglycaemic compound pent-4-enoic acid and related nonhypoglycaemic fatty acids. Bio- chem. J., 110: 499 (1968)

14. Senior, A. E., Robson, B., and Sherratt, H. S. A.: Biochemical effects of the hypoglycaemic compound pent-4-enoic acid and related nonhypoglycaemic fatty acids. Biochem. J., 110: 511 (1968).

15. Sherratt, H. S. A.: Hypoglycin and related hypoglycaemic compounds. Brit. Med. Bull., 25: 250 (1969).

16. Shib, V E and Efron, M L. Urea cycle disorders. In: J. B Stanbury, J. B. Wyngaarden, and D. S. Fredrickson: The Metabolic Basis of Inherited Disease, Ed. 3, pp. 370-392 (McGraw-Hill Book Co., New York, 1972).

17. Sinatra, F., Yoshida, T., Applebaum, M., Mason, W., Hoogenraad, N. H., and Sunshine, P.: Abnormalities of carbamyl phosphate synthetase and ornithine transcarbamylase in liver of patients with Reye's syndrome. Pediat. Res., 9: 829 (1975).

18. Trauner, D. A., Hyhan, W L., and Sweetman, L. Short chain organic acidemia and Reye's syndrome. Neurology, 25: 296 (1975).

19. New England Nuclear, Boston, Mass

20. Sigma, St. Louis, Mo.

21. Amersham Searle, Arlington Heights, III.

22. Liquimat Picker Nuclear, White Plains, N. Y

23. Requests for reprints should be addressed to: A. M. Glasgow, M.D., Children's Hospital National Medical Center, 2125 13th St., Washington, D. C. 20009 (USA).

24. Accepted for publication February 17, 1976
Familial hyperlysinemia lysine

fibroblasts

genetic disease

liver lysine-ketoglutarate reductase saccharopine dehydrogenase saccharopine oxidoreductase

\title{
Multiple Enzyme Defects in Familial Hyperlysinemia
}

\author{
J. DANCIS, ${ }^{(30)}$ J. HUTZLER, N. C. WOODY, AND R. P. COX \\ Department of Pediatrics and Department of Medicine, New York University School of Medicine, New York, New York; and \\ Department of Pediatrics, Tulane University School of Medicine, New Orleans, Louisiana, USA
}

\section{Extract}

Lysine-ketoglutarate reductase (EC. 1.5.1.8) deficiency in skin fibroblasts has been previously reported in patients with familial hyperlysinemia, providing an adequate explanation for the biochemical derangements noted clinically. In the present study, analysis of liver obtained at autopsy from a patient with familial hyperlysinemia confirmed the lysine-ketoglutarate reductase deficiency but, unexpectedly, also revealed an absence of saccharopine dehydrogenase (EC. 1.5.1.9) and saccharopine oxidoreductase activity. Skin fibroblasts from two siblings with the disease and a third patient from an unrelated family were also deficient in all three enzymes (lysine-ketoglutarate reductase, average 9\%; saccharopine dehydrogenase, average $4 \%$; saccharopine oxidoreductase, $<10 \%$ of normal). The possibility that saccharopine dehydrogenase is a substrate-inducible enzyme was investigated by maintaining normal skin fibroblasts in a medium with minimal lysine concentration, and exposing hyperlysinemic fibroblasts to elevated saccharopine concentrations. There was no significant modification in saccharopine dehydrogenase activity.

\section{Speculation}

Multiple enzyme defects have now been recognized in three genetic diseases, maple syrup urine disease, orotic aciduria, and hyperlysinemia, presumably arising from single mutations. It is not unlikely that additional examples will emerge as investigators increase their efforts in this direction. The simultaneous loss of enzymes may provide insights into mechanisms of control and/or the evolutionary development of enzymes.

Familial diseases with a Mendelian pattern of inheritance are generally attributed to mutation of a single gene. It follows from the "one gene-one enzyme" dictum that the primary defect should involve one enzyme. The broader statement of the concept "one gene-one polypeptide" suggests that more than one gene may direct the synthesis of one enzyme but leaves undisturbed the thesis that a genetic disease should cause one defective enzyme. Experience with an ever enlarging series of genetic diseases has supported the general applicability of the concept. There have been two noteworthy exceptions: maple syrup urine disease and orotic aciduria. The present study shows that familial hyperlysinemia is also an exception.

Familial hyperlysinemia was described in 1964. Elucidation of the enzyme defect followed a logical sequence. A severe reduction in the capacity to degrade lysine was demonstrated in two siblings after the administration of radioactive lysine $(26,27)$. Studies of skin fibroblasts grown in tissue culture identified the defective enzyme as lysine-ketoglutarate reductase (EC. 1.5.1.8) (6). This enzyme catalyzes the first step in the degradative pathway of lysine, the conversion of lysine to saccharopine (Fig. 1).

The recent death of an affected child in the original family has permitted an investigation of lysine metabolism in liver. The unexpected observation that more than one enzyme was defective led to further studies using skin fibroblasts of affected children. 
(1b)

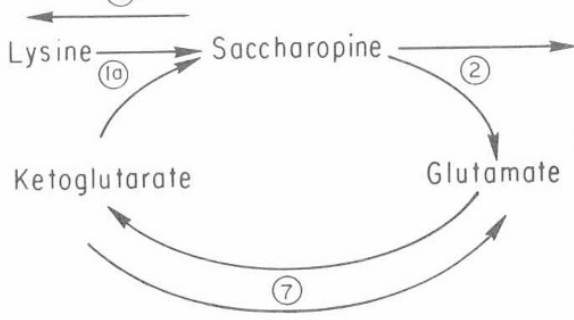

Aminoadipicsemialdehyde<smiles>C1#CC=C1</smiles>
Pipecolic acid

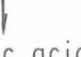
(3) Aminoadipate Ketoadipate
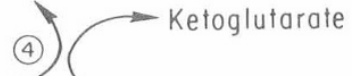

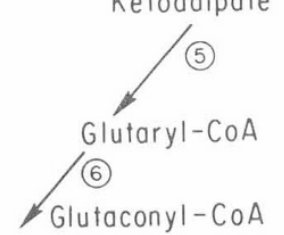

Fig. 1. Partial pathway of L-lysine catabolism.

\begin{tabular}{cllr}
\hline Reaction & \multicolumn{1}{c}{ Enzyme name } & \multicolumn{1}{c}{ Associated inborn error } & References \\
\hline$l a$ & Lysine-ketoglutarate reductase & Hyperlysinemia & $(1,5,6,13)$ \\
$1 b$ & Saccharopine oxidoreductase & Hyperlysinemia & This article \\
2 & Saccharopine dehydrogenase & Saccharopinuria, hyperlysinemia & $(9)$ \\
3 & Aminoadipic-semialdehyde oxidase & Hyperpipecolatemia & $(12)$ \\
4 & Aminoadipic aminotransferase & $\alpha$-Amino adipic aciduria & $(11)$ \\
5 & Ketoadipic acid decarboxylase & Ketoadipic aciduria & $(22,24,25)$ \\
6 & Glutaryl-CoA decarboxylase & Glutaric aciduria & $(14)$ \\
7 & Glutamic dehydrogenase & & 2
\end{tabular}

${ }^{1}$ Suggestive evidence only, not confirmed by specific assay. In mammals, the degradation of saccharopine has not been shown to involve a separate intermediate step through the semialdehyde.

${ }^{2}$ No enzyme defect has been described for this enzyme.

\section{CASE HISTORIES}

$P J a, A J a$, and $J J a$ are siblings of a consanguineous marriage. Mental retardation was a significant clinical feature in only the propositus $(P J a)$. Detection of hyperlysinemia in the propositus was the result of the common practice of investigating children with mental deficiency for metabolic defects, and the inborn error is not believed to be the cause of her retardation. PJa died at 13 years of age following 3 days of severe pneumonia. Autopsy confirmed the clinical diagnosis. Grossly the liver appeared normal with minimal fatty change and passive congestion noted microscopically. $A J a$ is now $10 \% / 12$ years old and is normal mentally and physically. $\mathrm{JJa}$ is $12^{3} / 12$ years old, has bilateral lens dislocations, and is considered to be a slow learner. There is some question as to whether he may be slightly retarded.

$A R o$ was found to be hyperlysinemic in the Massachusetts Screening Program. He has grown and developed normally. Skin fibroblasts grown from biopsies on all four patients revealed lysine-ketoglutarate reductase deficiency $(1,5,6)$.

\section{BIOLOGIC SAMPLES}

Liver was obtained at autopsy from $P J a 2 \mathrm{hr}$ after death and maintained at $-20^{\circ}$ until analyzed. Control liver was obtained at autopsy from a young adult approximately $12 \mathrm{hr}$ after a traumatic death and shortly after the death of PJa. The control specimen was stored with the tissue from $P J a$.

Skin biopsies has been obtained in 1968 from $A J a$ and $J J a$ and early passage fibroblasts were stored under liquid nitrogen. Samples were thawed and regrown for the present studies. Fresh biopsies were also obtained and new cultures started. The results on stored and fresh fibroblasts were the same.

\section{METHODS}

\section{PREPARATION OF LIVER FRACTIONS}

The methods have been described in detail previously (17). In brief, liver was homogenized in $\mathrm{NaCl}$, the suspension treated with $2 \%$ protamine sulfate, then centrifuged and filtered. Sodium citrate was added to the supernatant and the protein fraction that precipitated between $0.75 \mathrm{M}$ and $1.15 \mathrm{M}$ was retained and redissolved in buffered saline.

\section{ISOLATION OF MITOCHONDRIA FROM FIBROBLASTS}

Fibroblasts were grown to confluence in Eagle's minimal essential medium (MEM) with $15 \%$ fetal calf serum and antibiotics (penicillin $50 \mathrm{U} / \mathrm{ml}$, streptomycin $50 \mu \mathrm{g} / \mathrm{ml}$, and kanamycin $30 \mu \mathrm{g} / \mathrm{ml}$ ). Usually cells from one Blake bottle, $180 \mathrm{~cm}^{2}$ of growing surface (approximately 4-6 million cells), were used for each assay. At the time of assay, the normal cells had grown for 8-27 generations and the hyperlysinemic cells for 6-18 generations. They were harvested by replacing the growth medium with $11 \mathrm{ml}$ cold $0.23 \mathrm{M}$ sucrose solution containing $\mathrm{N}$-2-hydroxyethylpiperazine- $N^{\prime}$-2-ethanesulfonic acid (HEPES)- $\mathrm{NaOH}$ buffer 2 $\mathrm{mM}(\mathrm{pH} 7.5)$, and EDTA $0.2 \mathrm{mM}$. A rubber policeman was used to scrape the cells into the solution. The cells were chilled in an ice bath for $3 \mathrm{~min}$ and were kept cold throughout the isolation and sonication procedures. Homogenization was for $3 \mathrm{~min}$ in a Potter-Elvehjem Teflon pestle homogenizer. One milliliter of 0.5 M sucrose solution was added when the homogenization was complete. The homogenate was transferred to a 15 -ml polycarbonate centrifuge tube and centrifuged for $10 \mathrm{~min}$ in a Lourdes high speed refrigerated centrifuge using the 9RA fixed-angle head at $600 \times g$. The supernatant was transferred by Pasteur pipette and centrifuged at $10,000 \times g$ for $15 \mathrm{~min}$.

To the small pellet which contained the mitochondria was added $0.15 \mathrm{ml}$ of a solution of $0.14 \mathrm{M} \mathrm{KCl}$ containing $N$-tris-(hydroxymethyl)methyl glycine (Tricine) $50 \mathrm{mM}(\mathrm{pH} \mathrm{8.8)}$. EDTA $1 \mathrm{mM}$, and 2-mercaptoethanol $1 \mathrm{mM}$. The mitochondria pellet was dispersed and disrupted with a Branson model W140 Sonifier using the $3-\mathrm{mm}$ diameter microtip. Sonication was for $9 \times 10 \mathrm{sec}$ at slightly less than the maximum that could be applied without causing foaming. Twenty seconds of cooling time were allowed between periods of sonication. Protein content of isolated mitochondria was $150-550 \mu \mathrm{g}$ or approximately $5-12 \%$ of protein in the intact cells.

\section{ANALYTIC METHODS}

\section{LYSINE-KETOGLUTARATE REDUCTASE}

The reaction mixture contained $\mathrm{L}-\left[\mathrm{U}-{ }^{14} \mathrm{C}\right] l y s i n e, 0.5 \mu \mathrm{Ci}, 1.0$ $\mu$ mol; potassium $\alpha$-ketoglutarate, $2 \mu$ mol: potassium phosphate, $15 \mu \mathrm{mol}(\mathrm{pH} 7.1$ ): NADPH, $1.5 \mu \mathrm{mol}$; and mitochondrial enzyme preparation from fibroblasts and water to a final volume of $0.5 \mathrm{ml}$. 
The mixture was incubated at $30^{\circ}$ for $20 \mathrm{~min}$ as described previously (6). The saccharopine formed was isolated by high voltage electrophoresis at $\mathrm{pH} 6.7$ followed by ion exchange chromatography and determination of radioactivity in the isolated saccharopine.

Liver enzyme was measured spectrophotometrically using 0.2 $\mathrm{ml}$ extract in a total volume of $1 \mathrm{ml}$ as described previously (17).

\section{SACCHAROPINE DEHYDROGENASE (EC. 1.5.1.9)}

The method of Fellows and Carson (9) was modified in two significant respects, permitting satisfactory assays with approximately one-tenth the amount of fibroblasts. Repetitive washing and centrifuging of mitochondria were abandoned, substituting instead a single, closely controlled centrifuging. The smaller quantity of product, radioactive glutamate, was assayed by the specific enzyme, glutamate decarboxylase, in preference to isolation with high voltage electrophoresis.

To $0.1 \mathrm{ml}$ sonicated mitochondrial preparation was added 0.5 $\mu$ mol NAD ${ }^{+}$in $0.02 \mathrm{ml} \mathrm{l} \mathrm{M}$ Tricine- $\mathrm{NaOH}$ buffer $(\mathrm{pH} 8.9)$, saccharopine-([U- $\left.{ }^{14} \mathrm{C}\right]$ glutaryl $), 0.1 \mu \mathrm{Ci}, 0.1 \mu \mathrm{mol}$, and water to a volume of $0.25 \mathrm{ml}$. The reaction was allowed to proceed with agitation in a Dubnoff metabolic incubator for $60 \mathrm{~min}$ at $25^{\circ}$ and was stopped by adding $0.1 \mathrm{ml} 10 \mathrm{mM}$ glutamate solution, then 0.05 $\mathrm{ml} 1 \mathrm{~N} \mathrm{HCl}$. After $10 \mathrm{~min}$ the $\mathrm{pH}$ was adjusted to approximately 5 , as determined by narrow range $\mathrm{pH}$ paper, by the addition of $1 \mathrm{~N}$ $\mathrm{NaOH}$. One-tenth milliliter of potassium acetate, $0.4 \mathrm{M}(\mathrm{pH} 4.9)$, was added and the solution was centrifuged. The supernatant was analyzed for $\left[{ }^{14} \mathrm{C}\right]$ glutamate and the precipitate was analyzed for protein content. Two types of blank were used. In one the $\mathrm{HCl}$ was added immediately after adding enzyme; the other was a reagent blank without enzyme. The blanks averaged less than $100 \mathrm{cpm}$ and did not differ significantly.

The entire supernatant was preincubated in a vial, 19 by $48 \mathrm{~mm}$ (Kimble no. 60975-L). After 60 min $2 \mathrm{U}$ glutamic decarboxylase and $10 \mu \mathrm{g}$ pyridoxal phosphate in $0.1 \mathrm{ml}$ acetate buffer were added. A stopper holding a well charged with $0.1 \mathrm{ml} 1 \mathrm{~N} \mathrm{KOH}$ was also added. Incubation was for $90 \mathrm{~min}$ at $25^{\circ}$. The $\mathrm{KOH}$ was then transferred quantitatively to a scintillation counting vial. The vial contained $12 \mathrm{ml}$ scintillation cocktail containing, in approximately 1 liter, $640 \mathrm{ml}$ methanol, $320 \mathrm{ml}$ toluene, $20 \mathrm{ml}$ phenethylamine, 20 $\mathrm{ml}$ glycerol, $6 \mathrm{~g}$ methylbenzethonium chloride (Hyamine 10X), $6 \mathrm{~g}$ PPO, $120 \mathrm{mg}$ dimethyl-POPOP. Counting was done on a Packard Tri-Carb scintillation counter with approximately $65 \%$ efficiency for ${ }^{14} \mathrm{C}$ when counted in this cocktail. To determine the effectiveness of the glutamic decarboxylase, parallel samples of [U${ }^{14} \mathrm{C}$ lglutamate, $1 \mu \mathrm{mol}, 0.01 \mu \mathrm{Ci}$, were similarly treated and $90 \%$ of the expected radioactivity was recovered.

The previously described spectrophotometric assay (15), in which the reduction of $\mathrm{NAD}^{+}$is measured, was also used for assay of liver enzyme fractions.

\section{$\alpha$-AMINOADIPATE AMINOTRANSFERASE}

The assay method of Nakatani et al. (2l) measures the reverse reaction, the conversion of $\alpha$-ketoadipate and glutamate to $\alpha$-aminoadipate and $\alpha$-ketoglutarate. One product of the reaction, $\alpha$-ketoglutarate, is then measured by following the oxidation of $\mathrm{NADH}$ spectrophotometrically, in the presence of $\mathrm{NH}_{3}$ and glutamic dehydrogenase.

\section{SACCHAROPINE OXIDOREDUCTASE}

A modification of Fellows' method $(8,9)$ was used. Radioactive saccharopine $\left(\left[1-{ }^{14} \mathrm{C}\right]\right.$ lysyl $)$ was incubated in the presence of $\mathrm{NH}_{3}$, $\mathrm{NADP}^{+}$, and glutamic dehydrogenase. The last served to keep one product of the reaction, $(\gamma$-ketoglutarate, from accumulating. A second product $\left(\left[1-{ }^{14} \mathrm{C}\right]\right.$ lysine $)$ was measured by incubating with lysine decarboxylase and collecting ${ }^{14} \mathrm{CO}_{2}$. The details of the modified assay were as follows.

The medium was decanted from one confluent bottle of fibroblasts and replaced with $10 \mathrm{ml} 0.15 \mathrm{M} \mathrm{NaCl}$. Fibroblasts were scraped into the $\mathrm{NaCl}$ solution using a rubber policeman. They were then pipetted into a centrifuge tube and centrifuged briefly and the supernatant discarded. To the cell button was added $0.1 \mathrm{ml}$ $0.15 \mathrm{M} \mathrm{KCl}$ and the tube was alternated between a Dry Icemethanol bath and a $23^{\circ}$ water bath for 10 freeze-thaw cycles in approximately $60 \mathrm{~min}$ total time. The cells were stirred with a glass rod during this procedure but were not otherwise mechanically disrupted. The complete freeze-thaw lysate was used as the enzyme source.

Buffer and $\mathrm{NH}_{4} \mathrm{Cl}$ were prepared as a single concentrate to keep incubation volumes small. Tricine, $8.96 \mathrm{~g}$, and $\mathrm{NH}_{4} \mathrm{Cl}, 1.34 \mathrm{~g}$, were dissolved in $35 \mathrm{ml}$ water. $\mathrm{NaOH}, 50 \%$, was added to a final $\mathrm{pH}$ of 8.9 (glass electrode, $25^{\circ}$ ) and the solution was diluted to $50 \mathrm{ml}$ with water. This solution must remain tightly stoppered because the ammonia is volatile at this $\mathrm{pH}$. A final ammonia concentration of $80 \mathrm{mM}$ is essential to the reaction (8).

Fifty microliters of a freshly prepared solution containing in each sample, $32 \mu \mathrm{l}$ buffer- $\mathrm{NH}_{3}$ solution, $0.5 \mu$ mol NADP ${ }^{+}, 10 \mu \mathrm{l}$ $\left[{ }^{14} \mathrm{C}\right]$ saccharopine, and $8 \mu \mathrm{l}$ glutamic dehydrogenase (approximately 4 units), were added to each enzyme sample to be assayed. Water was added to a final volume of $0.20 \mathrm{ml}$.

The tubes were tightly stoppered and incubated for $60 \mathrm{~min}$ at $30^{\circ}$. The reaction was terminated by adding $0.05 \mathrm{ml} 10 \mathrm{mM}$ lysine

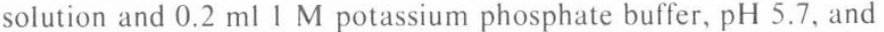
placing the tubes in boiling water bath for $2 \mathrm{~min}$ followed by centrifugation.

To determine the lysine formed by the saccharopine oxidoreductase reaction, the supernatant of each tube was transferred to a vial ( 19 by $48 \mathrm{~mm}$ ) and was placed on a $30^{\circ}$ water bath (unstoppered) for $30 \mathrm{~min}$. From a freshly made mixture, $0.5 \mathrm{U}$ lysine decarboxylase and $5 \mu \mathrm{g}$ pyridoxal phosphate in $0.1 \mathrm{ml}$ phosphate buffer were added. The vials were immediately closed with stoppers (Kontes Glass Company, no. K882330) with a centerwell containing $0.1 \mathrm{ml}$ $1 \mathrm{~N} \mathrm{KOH}$. A blank and a sample $\mathrm{L}-\left[1-{ }^{14} \mathrm{C}\right]$ lysine containing approximately $10,000 \mathrm{cpm}$ were also carried through the assay. The latter acts as a control of the decarboxylation reaction, which is normally $90 \%$ or more complete. After $90 \mathrm{~min}$ at $30^{\circ}$ the contents of the wells were transferred to scintillant and the ${ }^{14} \mathrm{CO}_{2}$ was counted. The precipitate was dissolved in $1 \mathrm{M} \mathrm{NaOH}$ and protein was determined by the method of Lowry et al. (20).

\section{TISSUE CULTURE}

Methods for establishing cultures from skin biopsies and passaging cells have been previously described $(3,4)$. Modulation of the activity of the saccharopine cleavage enzyme in normal and hyperlysinemic fibroblasts was studied by growing cells for 10 days in medium containing a final concentration of $1 \mathrm{mM}$ saccharopine. The effect of limiting lysine on the activities of the enzymes in the lysine degradation pathway was investigated in normal fibroblasts by propagating them in MEM containing $5.8 \mathrm{mg} /$ liter lysine, which is one-tenth of the normal concentration, for 5 days, at which time the monolayers were confluent. This concentration of lysine was determined to be the lowest capable of supporting cell growth. The medium was replaced with MEM without lysine and the monolayers were incubated for an additional 4-10 days before assay. All determinations were carried out in triplicate and in each assay replicate cultures grown in complete medium were used as controls.

\section{MATERIALS}

Saccharopine-([U-14 C glutaryl), saccharopine-([1- $\left.{ }^{14} \mathrm{C}\right]$ lysyl), and nonradioactive saccharopine were synthesized in this laboratory by previously described enzymatic methods (15). Precautions were taken to remove traces of $\mathrm{NH}_{3}$ from the reagents when preparing glutaryl-labeled saccharopine in order to avoid formation of glutamate. The $\left(\gamma-\left[\mathrm{U}-{ }^{14} \mathrm{C}\right] \mathrm{ket}\right.$ oglutarate was adjusted to $\mathrm{pH}$ 2 and passed through a column $\left(1\right.$ by $6 \mathrm{~cm}$ ) of Dowex $50, \mathrm{H}^{+}$form. Sucrose was "ultra-pure" (Schwartz-Mann). Glutamic and lysine 
decarboxylases were type II purified from Escherichia coli and Bacillus cadaveris, respectively. The decarboxylases, cofactors, and most other biochemicals were from Sigma Chemical Co. Water was double-distilled in glass.

\section{RESULTS}

Several enzymes involved in lysine degradation were measured in liver obtained from a hyperlysinemic child and from a control subject (Table 1). There was no detectable activity for lysine-ketoglutarate reductase or saccharopine dehydrogenase in the hyperlysinemic liver. The methods could have detected less than $1 \%$ of the activity found in the control liver. Analysis of saccharopine oxidoreductase yielded $12 \mathrm{cpm}$ over a blank of 34 . This amount of activity was equivalent to $3 \%$ of normal, but is of questionable accuracy. The activities of $\alpha$-aminodipate aminotransferase and glutamate deydrogenase were lower in the hyperlysinemic liver than in the control, but considerable activity remained.

Skin fibroblasts grown in tissue culture were assayed for saccharopine dehydrogenase activity (Table 2 ). The results with three hyperlysinemia patients (two of the $J a$ family and an unrelated child, $A R O$ ) are compared with a series of normal subjects. Less than $10 \%$ of normal activity was detected in the hyperlysinemia patients, similar in magnitude to that previously reported in the same subjects for lysine-ketoglutarate reductase activity (Table 3). Fibroblasts from PJa, the donor of the liver, were not available for study.

Saccharopine oxidoreductase activity was measured in fibroblasts from two hyperlysinemic children from unrelated families, and from two control subjects (Table 4). The activity of this enzyme in normal subjects is considerably less than that of the enzyme catalyzing the forward reaction, lysine-ketoglutarate reductase. It was estimated that $10 \%$ of normal enzyme activity could be detected with confidence (radioactivity of 2 times the blank). The enzyme activity in the hyperlysinemic children was considerably below that level.

The possibility that saccharopine dehydrogenase is an inducible enzyme was investigated in two ways: normal cells were grown in medium containing limited concentrations of lysine (one-tenth normal level) and then were maintained for 4-10 days in medium containing no lysine. Hyperlysinemic cells (from patients $J J a$ and $A R O)$ were grown in medium containing $1 \mathrm{mM}$ saccharopine for 10 days (Tables 5 and 6). Neither manipulation significantly changed the level of saccharopine dehydrogenase activity. The apparent increase in lysine-ketoglutarate activity in normal cells after reduction of lysine concentration in the medium is probably caused by a higher specific activity of the substrate as a result of lowering intracellular levels of lysine.

\section{DISCUSSION}

Enzymatic analysis of liver obtained at autopsy from a patient with hyperlysinemia confirmed the previously reported deficiency of lysine-ketoglutarate reductase activity in skin fibroblasts (Table 1). With an assay capable of easily detecting less than $1 \%$ of the activity in normal liver, there was no detectable activity in the hyperlysinemic liver. Skin fibroblasts from this patient had a residual activity of approximately $7 \%$ of normal. The difference in magnitude of the defect in liver and in fibroblasts is most readily explained by instability of the mutant enzyme which caused rapid disappearance of residual activity from the liver after death. Instability of the mutant enzyme on storage has been described in hypoxanthine phosphoribosyltransferase deficiency (7). This would be consistent with the observation that hyperlysinemic children, in vivo, can degrade about $20 \%$ as much lysine as control children (27). Alternate degradative pathways may also have been utilized. Isozymes of lysine-ketoglutarate reductase have not been reported.

The hyperlysinemic liver was also incapable of catalyzing the reverse reaction, the cleavage of saccharopine to lysine and $\alpha$-ketoglutarate. The small amount of residual activity reported in Table 1 is beyond the sensitivity of the analytic technique and it is not certain that any enzymatic activity was detected. Fellows (8) contends that in ox liver this metabolic step is performed by an enzyme distinct from lysine-ketoglutarate reductase and has named the enzyme saccharopine oxidoreductase. Studies of human placenta also suggest that saccharopine oxidoreductase and lysineketoglutarate reductase may be two distinct enzymes (10). An active lysine-ketoglutarate reductase was present but the reverse reaction (saccharopine to lysine) could not be demonstrated. However, the evidence is not conclusive, and it may be that in man one enzyme, lysine-ketoglutarate reductase, catalyzes the reaction in both directions with the equilibrium predominantly towards saccharopine synthesis.

A surprising observation in the study of the hyperlysinemic liver was the absence of activity of the second degradative enzyme in the lysine pathway, saccharopine dehydrogenase (Table 1). An important question in evaluating these observations is the physiologic

Table 2. Saccharopine dehydrogenase activity in skin fibroblasts ${ }^{1}$

\begin{tabular}{|c|c|c|c|c|}
\hline & Controls & $A J a$ & $J J a$ & $A R O$ \\
\hline Number of assays & $12^{2}$ & 2 & 6 & 3 \\
\hline $\begin{array}{l}\text { Average enzyme ac- } \\
\text { tivity }\end{array}$ & 8.23 & 0.16 & 0.29 & 0.55 \\
\hline Range & 4.9-19.9 & $0-0.32$ & $0-0.9$ & $0-1.1$ \\
\hline Percent normal & $(100)$ & 1.9 & 3.5 & 6.7 \\
\hline
\end{tabular}

${ }^{1}$ Enzyme activity is measured in nanomoles per $\mathrm{mg}$ mitochondrial protein in $60 \mathrm{~min}$.

${ }^{2}$ Eight individuals.

Table 3. Lysine-ketoglutarate reductase in skin fibroblasts ${ }^{1}$

\begin{tabular}{lcccrr}
\hline & Controls & AJa & JJa & PJa & ARo \\
\hline Enzyme activity & 351 & 37 & 35 & 23 & 26 \\
Percent normal & $(100)$ & 11 & 10 & 7 & 8 \\
\hline
\end{tabular}

${ }^{1}$ Assays performed on disrupted fibroblasts in this laboratory as reported previously (see Table 1, Reference 6). ARo (5) will be reported separately (1). Enzyme activity is measured in picomoles per min per $\mathrm{mg}$ protein.

Table 1. Enzyme activity in liver ${ }^{1}$

\begin{tabular}{lcccc}
\hline \multicolumn{1}{c}{ Subject } & $\begin{array}{c}\text { Lysine-ketoglutarate } \\
\text { reductase }\end{array}$ & $\begin{array}{c}\text { Saccharopine } \\
\text { dehydrogenase }\end{array}$ & $\begin{array}{c}\text { Saccharopine } \\
\text { oxidoreductase, } \\
\times 10^{4}\end{array}$ & $\begin{array}{c}\text { Aminoadipate } \\
\text { transferase, } \\
\times 10^{-3}\end{array}$ \\
$\begin{array}{lccc}\text { Glutamic } \\
\text { dehydrogenase }\end{array}$ \\
$\begin{array}{l}\text { Hyperlysinemia }(P J a) \\
\text { Control }\end{array}$ & 0 & 0 & $0.03^{2}$ & 1.09 \\
\hline
\end{tabular}

${ }^{a}$ Enzyme activities were measured in the citrate-precipitated fraction, prepared as described in the text, except for $\alpha$-aminoadipic aminotransferase, which was assayed in the protamine supernatant. Activity is measured in nanomoles per min per mg protein.

${ }^{2}$ Below limits of accuracy of analytic technique. 
Table 4. Saccharopine oxidoreductase in skin fibroblasts ${ }^{1}$

\begin{tabular}{cccc}
\hline Subjects & Controls & $J J a$ & ARo \\
\hline $\begin{array}{c}\text { Average enzyme } \\
\text { activity }\end{array}$ & 15.5 & $0.5^{2}$ & $0.01^{2}$ \\
Percent normal & $(100)$ & $3.4^{2}$ & $0.5^{2}$ \\
\hline
\end{tabular}

${ }^{1}$ Assays were performed on disrupted fibroblasts as described under Methods. Enzyme activity is measured in picomoles per min per $\mathrm{mg}$ cell protein.

${ }^{2}$ Represents $20(J J a)$ and $2 \mathrm{cpm}(A R O)$ above a blank of 73 , at and below the limits of confidence of the analytic technique.

Table 5. Response of normal skin fibroblasts to reduction of lysine in growth media ${ }^{1}$

\begin{tabular}{|c|c|c|}
\hline Growth medium & $\begin{array}{l}\text { Lysine-ketoglutarate } \\
\text { reductase }\end{array}$ & $\begin{array}{l}\text { Saccharopine } \\
\text { dehydrogenase }\end{array}$ \\
\hline $\begin{array}{l}\text { Complete } \\
\text { Complete }\end{array}$ & $\left.\begin{array}{r}138 \\
95\end{array}\right\} 117$ & $\left.\begin{array}{l}143 \\
170\end{array}\right\} 157$ \\
\hline $\begin{array}{l}\text { Reduced lysine } \\
\text { Reduced lysine }\end{array}$ & $\left.\begin{array}{l}476 \\
343\end{array}\right\} 410$ & $\left.\begin{array}{l}252 \\
242\end{array}\right\} 247$ \\
\hline
\end{tabular}

${ }^{1}$ Enzyme activity is measured in picomoles per min per mg protein. Lysine concentration of medium was reduced to $0.04 \mathrm{mM}$, about one-tenth the usual concentration. Cells were grown for 6 days and then the medium was replaced by medium without lysine and the fibroblasts were incubated for an additional 4 days.

Table 6. Response of hyperlysinemic fibroblasts to increased levels of saccharopine in growth media ${ }^{1}$

\begin{tabular}{|c|c|c|}
\hline & \multicolumn{2}{|c|}{ Growth medium } \\
\hline & Complete & $\begin{array}{c}\text { Complete }+ \\
\text { saccharopine }(1 \mathrm{mM})\end{array}$ \\
\hline \multirow[t]{2}{*}{$J J a$} & 0 & 0 \\
\hline & 0 & 0 \\
\hline \multirow[t]{2}{*}{ Control } & 6.8 & \\
\hline & 13.8 & \\
\hline \multirow[t]{2}{*}{$A R O$} & 1.32 & 1.00 \\
\hline & 1.26 & 0.34 \\
\hline \multirow[t]{2}{*}{ Control } & 10.6 & \\
\hline & 11.0 & \\
\hline
\end{tabular}

\footnotetext{
${ }^{\mathrm{I}}$ Saccharopine dehydrogenase activity is measured in nanomoles per $\mathrm{mg}$ protein in $60 \mathrm{~min}$.
}

state of the liver at the time of analysis. To control this factor, liver was obtained at autopsy from an unaffected male adult and maintained in storage with the hyperlysinemic liver. All assays were done concurrently with both livers. A further check on the "viability" of the liver was provided by measuring two additional enzymes intimately involved in lysine metabolism, glutamic dehydrogenase and $\alpha$-aminoadipic transferase (Fig. 1). Both were easily demonstrable in the hyperlysinemic liver. The activities were approximately $40 \%$ of the control liver, contrasting with the nondetectable activities of lysine-ketoglutarate reductase, saccharopine oxidoreductase, and saccharopine dehydrogenase.

The evidence for a specific defect in liver in the three enzymatic conversions appeared strong. However, further support was sought in skin fibroblasts grown in tissue culture. Study of skin fibroblasts provided the additional advantage of determining whether the multiple enzyme defect was peculiar to one patient with hyper- lysinemia or had more general significance. Available to us, in storage, were fibroblasts from two siblings of the deceased patient and from another unrelated patient with hyperlysinemia. Fresh biopsies were also obtained from the siblings to eliminate any remote possibility of changes during storage. Previous studies had demonstrated a deficiency in lysine-ketoglutarate reductase activity in skin fibroblasts in all subjects (Table 3), and the present studies revealed a deficiency in saccharopine dehydrogenase ( $\mathrm{Ta}$ ble 2). By modifications of the technique described by Fellows to measure saccharopine oxidoreductase (8), the sensitivity was increased so that the enzyme could be regularly demonstrated in normal skin fibroblasts. There was considerable reduction in saccharopine oxidoreductase activity in the hyperlysinemic fibroblasts, also (Table 4).

The possibility was entertained that saccharopine dehydrogenase was a substrate-induced enzyme and that its reduced activity was secondary to a deficiency in lysine-ketoglutarate reductase. To investigate this, hyperlysinemic cells were maintained in tissue culture in medium containing saccharopine $1 \mathrm{mM}$ for 10 days. There was no increase in activity of saccharopine dehydrogenase. Conversely, normal cells grown with limiting lysine were exposed to medium without lysine for 4-10 days. There was an apparent increase in lysine-ketoglutarate reductase activity, possibly attributable to reduced dilution of the radioactive substrate by a smaller endogenous pool of lysine. Saccharopine dehydrogenase activity was not changed.

Multiple enzyme defects in genetic diseases are distinctly unusual. Maple syrup urine disease is probably the best known of these exceptions. Classic maple syrup urine disease and all of the variants described so far affect the oxidative-decarboxylation of the three branched-chain keto acids concordantly and to the same level. Bowden and Connelly (2) have presented evidence that valine decarboxylase is distinct from the decarboxylases of the other two keto acids.

Hereditary orotic aciduria is more analogous to familial hyperlysinemia in that two sequential metabolic steps are involved. Orotic acid is converted to uridine monophosphate by phosphorylation (orotidylic pyrophosphorylase) and then decarboxylation (orotidylic decarboxylase). Type I orotic aciduria, paralleling hyperlysinemia, is associated with a deficiency in both enzymes; type II orotic aciduria, similar to saccharopinuria, affects only the second enzyme (23). Krooth (18) has speculated that the double enzyme defect in type I orotic aciduria could be explained if the product of the first enzyme, orotidine monophosphate, stabilized the second enzyme. That explanation appears to be excluded in hyperlysinemia by the negative results from the addition of saccharopine to hyperlysinemic fibroblasts in tissue culture (Table 6).

Molecular explanations of the observations in familial hyperlysinemia must remain speculative without better information concerning the composition and structure of the involved enzymes. It is possible that one protein subserves the three enzymatic functions and the mutation interferes with synthesis of that protein. The existence of saccharopinuria as a separate metabolic defect would require that at least one polypeptide under separate genetic control be essential for only saccharopine dehydrogenase activity, and not for either lysine-ketoglutarate reductase or saccharopine oxidoreductase activity (9). It is also possible to visualize three individual enzymes as components of one macromolecule, with simultaneous loss of all three as a result of one mutation. Another possible mechanism is that described in microorganisms, a mutation in a regulatory protein controlling the synthesis of several enzymes in a metabolic pathway. Selection from among these possibilities, and others, is not possible with available information.

\section{SUMMARY}

Analysis of liver obtained at autopsy from a patient with familial hyperlysinemia revealed a severe deficiency in lysine-ketoglutarate reductase, saccharopine dehydrogenase, and saccharo- 
pine oxidoreductase. The deficiencies were confirmed in skin fibroblasts from two siblings with the disease and a third patient from an unrelated family.

\section{REFERENCES AND NOTES}

1. Ampola, M. G., Ampola, M., Mian, M., Shaw, W., Levy, H., Letsou, A., and Doyle, M.: In preparation.

2. Bowden, J. A., and Connelly, J. L.: Branched-chain $\alpha$-keto acid metabolism. I Isolation, purification and partial characterization of bovine liver $\alpha$ ketoisocaproic: $\alpha$-keto- $\beta$-methylvaleric acid dehydrogenase. J. Biol. Chem. 243: 1198 (1968).

3. Cox, R. P., Krauss, M. R., Balis, M. E., and Dancis, J.: Communication between normal and enzyme deficient cells in tissue culture. Exp. Cell Res., 74: 251 (1972).

4. Cox, R. P., and MacLeod, C. M.: Alkaline phosphatase content and the effects of prednisolone on mammalian cell cultures. J. Gen. Physiol., 45: 439 (1962).

5. Dancis, J.: Abnormalities in the degradation of lysine. In: W. L. Nyhan: Heritable Disorders of Amino Acid Metabolism, Ed. 1, p. 387 (John Wiley and Sons, New York, 1974).

6. Dancis, J., Hutzler, J., Cox, R. P., and Woody, N. C.: Familial hyperlysinemia with lysine-ketoglutarate reductase insufficiency. J. Clin. Invest., 48: 1447 (1969)

7. Dancis, J., Yip, L. C., Cox, R. P., Piomelli, S., and Balis, M. E.: Disparate enzyme activity in erythrocytes and leucocytes: A variant of hypoxanthine phosphoribosyltransferase deficiency with an unstable enzyme. J. Clin. Invest. 52: 2068 (1973).

8. Fellows, F. C. I.: Biosynthesis and degradation of saccharopine, an intermediate of lysine metabolism. Biochem. J., 136: 321 (1973).

9. Fellows, F. C. I., and Carson, N. A. J.: Enzyme studies in a patient with saccharopinuria: A defect of lysine metabolism. Pediat. Res, 8:42 (1974).

10. Fjellstedt, T. A., and Robinson, J. C.: Purification and properties of L-lysine- $\alpha-$ ketoglutarate reductase from human placenta. Arch. Biochem. Biophys., 168 536 (1975).

11. Fisher, M. H., Gerritsen, T., and Opitz, J. M.: $\alpha$-Amino aciduria, a non-deleterious inborn metabolic defect. Humangenetik, 24: 265 (1974).

12. Gatfield, P. D., Taller, E., Hinton, G. G., Wallace, A. C., Abdelnour, G. M., and Haust, M. D.: Hyperpipecolatemia: A new metabolic disorder associated with neuropathy and hepatomegaly. A case study. Can. Med. Ass. J., 99: 1215 (1968)

13. Gelderen, H. H., and Teijema, H. L.: Hyperlysinemia: Harmless error of metabolism? Amer. J. Dis. Child., 48: 892 (1973).

14. Goodman, S. I., Markey, S. P., Moe, P. G., Miles, B. S., and Teng, C. C.:
Glutaric aciduria: A "new" disorder of amino acid metabolism. Biochem. Med., 12: 12 (1975)

15. Hutzler, J., and Dancis, J.: Saccharopine cleavage by a dehydrogenase of human liver. Biochim. Biophys. Acta, 206: 205 (1970).

16. Hutzler, J., and Dancis, J.: Preparative synthesis of saccharopine. Biochim Biophys. Acta, 222: 225 (1970)

17. Hutzler, J., and Dancis, J.: Lysine-ketoglutarate reductase in human tissues Biochim. Biophys. Acta, 377: 42 (1975).

18. Krooth, R. S.: Constitutive mutations and hereditary enzyme deficiencies in mammalian cells. In: M. Harris and B. Thompson: Regulation of Gene Expression in Eukaryotic Cells, p. 115 (Fogarty International Center, Bethesda, Md., 1973).

19. Lormans, S., and Lowenthal, A.: Amino adipic aciduria in an oligophrenic child Clin. Chim. Acta, 57: 97 (1974).

20. Lowry, O. H., Rosebrough, N. J., Farr, A. L., and Randall, R. J.: Protein measurement with the Folin phenol reagent. J. Biol. Chem. 193: 265 (1951).

21. Nakatani, Y., Fujioka, M., and Higashino, K.: $\alpha$-Aminoadipate aminotransferase of rat liver mitochondria. Biochim. Biophys. Acta, 198: 219 (1970).

22. Przyrembel, H., Bachmann, D., Lombeck, I., Becker, K., Wendel, U., Wadman, S. K., and Bremer, H. J.: Alpha-ketoadipic aciduria, a new inborn error of lysine metabolism; biochemical studies. Clin. Chim. Acta, 58: 257 (1975).

23. Smith, L. H., Jr., Huguley, C. M., Jr., and Bain, J. A.: Hereditary orotic aciduria. In: J. B. Stanbury, J. B. Wyngaarden, and D. S. Fredrickson: The Metabolic Basis of Inherited Diseases, Ed. 3, p. 1003 (McGraw Hill Book Co, New York, 1972).

24. Wendel, U., Rudiger, H. W., Przyrembel, H., and Bremer, H. J.: Alphaketoadipic aciduria: Degradation studies with fibroblasts. Clin. Chim. Acta, 58: 271 (1975)

25. Wilson, R. W., Wilson, C. M., Gates, S. C., and Higgins, J. V.: $\alpha$-ketoadipic aciduria: A description of a new metabolic error in lysine-tryptophan degradation. Pediat. Res., 9: 522 (1975).

26. Woody, N. C.: Hyperlysinemia. Amer. J. Dis. Child., 108: 543 (1964)

27. Woody, N. C., Hutzler, J., and Dancis, J.: Further studies of hyperlysinemia Amer. J. Dis. Child., 112: 577 (1966).

28. Informed consent for skin biopsy was obtained on all patients. The protocols for this procedure were reviewed and approved by the Committee for Protection of Human Subjects.

29. This study was supported by National Institutes of Health Grants HDO 4526 , AM 14528, and HDO 2920.

30. Requests for reprints should be addressed to: J. Dancis, M.D., Department of Pediatrics, New York University Medical Center, 550 First Ave., New York, N. Y. 10016 (USA).

31. Accepted for publication February 13, 1976.
Jejunal mucosa phosphate rickets, hypophosphatemic small intestine transport

\title{
Intestinal Phosphate Transport in Familial Hypophosphatemic Rickets
}

\author{
FRANCIS H. GLORIEUX, ${ }^{(36)}$ CLAUDE L. MORIN, ROSE TRAVERS, EDGARD E. DELVIN, AND \\ ROGER POIRIER
}

The Genetics Unit, Montreal Shriners Hospital; The Department of Paediatrics, University of Montreal; and The Departments of Paediatrics and Surgery, McGill University, Montreal, Quebec, Canada

\section{Extract}

The present report outlines an attempt to characterize inorganic phosphate uptake by human jejunal mucosa using biopsy material obtained from six patients affected by the X-linked form of vitamin D-resistant rickets and six control subjects.

The tissue from control subjects accumulated ${ }^{32} \mathrm{P}$ actively in a linear fashion against time. The incorporation of inorganic phosphate into organophosphate derivatives is rapid and equilibrates after $\mathbf{1 0} \mathrm{min}$ at an inorganic over total phosphate ratio of $\mathbf{0 . 4 5}$. Concentrative uptake and incorporation were both suppressed by anaerobiosis or cyanide. Rates of phosphate uptake and incorporation into the organic derivatives by the tissue of hypophosphatemic patients are comparable with normal values.

Saturation kinetics observed over a wide range of substrate concentrations $(0.003$ to $3 \mathrm{mM})$ elicits only one transport system with an apparent Michaelis constant of $0.2 \mathrm{mM}$ and a maximum velocity of $0.7 \mathrm{mmol} /$ liter $/ 40 \mathrm{~min}$. The kinetic data obtained from the patients do not strikingly differ from the control values. The chemical analysis of the phosphate content of intestinal mucosa from two patients and two control subjects indicates that the tissue is not specifically phosphate-depleted in the mutant individuals. 